\title{
Thank You for Sharing! \\ How knowledge sharing and information availability affect public employees' job satisfaction
}

This is an open access copy of the accepted author manuscript of the following article:

Fischer, C. and Döring, M. (2021), "Thank you for sharing! How knowledge sharing and information availability affect public employees' job satisfaction", International Journal of Public Sector Management.

https://doi.org/10.1108/IJPSM-10-2020-0290

The final formatted version is available from the publisher at: https://www.emerald.com/insight/content/doi/10.1108/IJPSM-10-20200290/full/html

Caroline Fischer (corresponding author)

c.fischer@utwente.nl

University of Twente

(D) 0000-0001-5870-4498

\section{Matthias Döring}

mdoering@sam.sdu.dk

Syddansk Universitet

(D) 0000-0002-5510-2579 


\begin{abstract}
Purpose

This research examines the impact of job-related knowledge sharing on information availability and job satisfaction for information-receiving employees in the public sector. Following self-determination theory, the study suggests that job satisfaction is only partly affected by knowledge sharing itself, but particularly through the availability of job-related information enabling the information receiver to work effectively.
\end{abstract}

\title{
Methodology
}

The hypotheses are tested with data from the U.S. Federal Employee Viewpoint Survey (FEVS) from 2018. Additionally, results are replicated with earlier waves of the survey.

\section{Findings}

Results show the positive impact of job-related knowledge sharing on job satisfaction, whereby the availability of job-relevant information mediates this relationship partially.

\section{Originality}

The results emphasize that knowledge sharing is a highly social process in which support and relatedness play a significant role for success in addition to the diffusion of information itself.

\section{Practical Implications}

This study confirms that managers should provide room for social interactions when introducing knowledge management practices. 


\section{INTRODUCTION}

The management of knowledge is currently a highly discussed topic in the public sector. Knowledge is considered to be the most vital resource in modern organizations (Nonaka and Takeuchi, 1995). This is especially the case in public sector organizations, which are characterized by knowledge-intensive work. At the same time, waves of retirement along with an imminent knowledge loss are predicted for the public sector. This development, threatening such an important resource, calls for knowledge management to conserve, diffuse, and utilize knowledge. Indeed, more and more public organizations are deciding to use wikis, intranets, knowledge-relays, and other mostly technological tools to organize their employees' knowledge, making it traceable and useable for the whole organization (Willem and Buelens, 2006).

Nonetheless, knowledge management is no end in itself and, therefore, its effects need to be examined. It is widely assumed that the transfer and storage of employees' knowledge will have a positive effect on an organization and its employees. However, empirical findings remain scarce, especially when it comes to the individual level - the impact of knowledge management on individual employees. This article sheds light on the impact at this analytical level. In doing so, we analyze the effects of knowledge sharing, as a focal activity in knowledge management, on employees' job satisfaction.

Studies on the relationship between knowledge sharing and outcomes at an individual level assume a direct relationship between knowledge sharing and satisfaction (e.g. Kianto et al., 2016) or performance (e.g. Henttonen et al., 2016). However, knowledge sharing can be ineffective when unusable amounts of knowledge are shared or when knowledge is flawed, inappropriately stored, or inaccessible. Based on self-determination theory (Deci et al., 1989), we argue that it is not necessarily the sharing of job-related knowledge which affects other employees in their role as information receivers, but ultimately the actual availability of the 
relevant information required to handle tasks well. Accordingly, the following research question is posed:

How do job-related knowledge sharing and information availability affect the information receiver's job satisfaction?

We analyze this research question using data from the U.S. Federal Employee Viewpoint Survey (FEVS) from 2018 and replicate the findings using earlier waves of the survey. We suggest that the relationship between knowledge sharing and job satisfaction is mediated by information availability and analyze this mediation model employing a causal-steps strategy with OLS regressions.

This study adds three essential contributions to the public administration and knowledge management literature, including correspondences between the two. First, this paper explains the impact of knowledge sharing and information availability on job satisfaction using selfdetermination theory. We not only test the effect of knowledge sharing on job satisfaction, but also propose a more detailed causal explanation and model this causal process both theoretically and empirically. Second, we contribute to the increasingly relevant research in the field of knowledge management in the public sector. Research on public sector knowledge management so far has mainly focused on the determinants of successful knowledge management. This study adds an analysis of the impact of knowledge sharing to this literature. Third, we offer important practical implications for public management. Knowledge sharing in the form of human interaction is shown to be a vital determinant in improving employees' job satisfaction. To make knowledge management successful, knowledge sharing activities should be fostered, instead of focusing on the mere availability of information. This is especially important for the public sector, where knowledge management has been applied with a focus on tools that neglect this social component, such as records or databases. 
The paper is organized as follows. First, we define basic terms and give an overview of empirical findings from the literature. Next, we derive the papers' hypotheses from the theoretical framework presented. After a short description of the method, we present and discuss the results of our analysis.

\section{STATE OF RESEARCH}

\section{Knowledge Management, Sharing, and Availability}

Knowledge is seen as one of the primary resources for organizations (among human, material, and financial resources) and knowledge management focuses on the question of how to make use of this resource (Holsapple et al., 2016). This study applies the term 'knowledge' in the sense of 'linked information', which can be shared by its owner. To make a clear distinction between knowledge and (stored) information, we work with the terms knowledge sharing and information availability.

Knowledge sharing is the exchange of knowledge among individuals, teams, units, or organizations (Paulin and Suneson, 2015). It is the critical part of knowledge management: "Simply put, a lack of sharing may inhibit or hinder knowledge management" (Law and Ngai, 2008, p. 2343) and "leveraging knowledge is only possible when people can share the knowledge they have and build on the knowledge of others" (Ipe, 2003, p. 341). Hence, knowledge sharing is considered to be an essential precondition for any management of knowledge.

Knowledge sharing, as well as knowledge management in general, have a common goal: the availability of (task-or job-relevant) information for employees (Ipe, 2003, p. 341). Information is available to receivers if it is traceable, as in if one can find it in a repository or 
identify a person who owns the information and is willing to share it. Availability also implies that relevant information is available to the extent and quality necessary.

Brown et al. (2013, p. 2018) measure this availability of information as the "existence of codified knowledge". In doing so, however, they neglect direct knowledge sharing in personal interactions, which may result in the availability of non-codified knowledge. Moffett and McAdam (2009, p. 52) refer to available information as "information flow" and their definition also encompasses activities of knowledge sharing. This article distinguishes between knowledge sharing as a behaviour and information availability as a result of this behaviour. We define the availability of information as codified and stored information, as well as the availability through person-to-person interaction. Although we suppose that while not every knowledge sharing behaviour results in information availability, information availability cannot arise without knowledge sharing. However, even if information is available it does not necessarily mean that an employee will be able to locate and use this information appropriately.

As the majority of literature on knowledge management focuses on private sector organizations, researchers in the field of public management often argue that findings from these studies cannot be easily transferred, due to the "unique characteristics in the public sector context" (Henttonen et al., 2016, p. 750). The literature shows that knowledge sharing in the public sector is constrained by organizational barriers associated with public organizations but fostered by individual determinants. While different antecedents of knowledge sharing have been investigated intensively (e.g., Cuganesan et al., 2016; Kim and Lee, 2006; Kim and Ko, 2014; Willem and Buelens, 2006) and there is a emerging literature on the organizational impact of knowledge sharing (e.g, Ahmad and Karim, 2019; Fischer, 2021; Yu et al., 2013), research on the effects of knowledge sharing on individual outcomes is lacking. Therefore, the aim of this study is to have a closer look at the outcomes of knowledge sharing in public organizations. 
It is commonly assumed that knowledge management has a positive impact on an organization and its employees (Eldor, 2018). Existing studies on work outcomes of knowledge management mainly analyse the impact on organizational performance (e.g., Andreeva and Kianto, 2012). In the public sector, conflicting goals and controversial discussions about the contribution of public administration to society complicate the definition and measurement of such outcomes (Rashman et al., 2009). However, knowledge management is associated with better service delivery and customer experience for citizens, improved onboarding of new employees (Colnar and Dimovski, 2017), and higher individual and organizational performance (Henttonen et al., 2016).

In this study, we focus on job satisfaction as an outcome of knowledge sharing. Job satisfaction is one of the major outcomes in management science, as it affects other outcomes such as employee performance (Hsieh, 2016), their psychological and physical health (Bond and Bunce, 2003), and commitment and turnover intention (Chordiya et al., 2017). Although job satisfaction is one of the most intensively studied variables in organizational research (Rainey, 2010), there is no single accepted definition of the concept. In this paper, job satisfaction is defined according to Gruneberg (1979) as the personal feeling about one's job and various aspects of it (similar: Judge et al., 2020; Fisher et al., 2016). Following this definition, job satisfaction can be identified as a global feeling of satisfaction concerning a job and also as reactions to particular conditions, such as pay, colleagues or tasks.

\section{THEORETICAL MODEL}

The majority of studies on knowledge management share a common assumption: they suggest a rather direct link from knowledge management to job satisfaction (Kianto et al., 2016). This study wants to shed more light on this causal link. We build on self-determination 
theory (Deci and Ryan, 2008; Deci et al., 1989) to explain the link between knowledge sharing by coworkers or the employer, hence the knowledge donators, and the job satisfaction of the information receiver. According to S-DT, human beings have an innate need to achieve competence, autonomy, and relatedness. The satisfaction of these needs predicts psychological well-being and a feeling of self-determination (Deci and Ryan, 2008). Competence is the need to be effective in dealing with the environment (Deci and Vansteenkiste, 2004). Autonomy is the need to be a causal agent, to experience volition and to act according to one's own interests and values (ibid.). Relatedness is the need to experience satisfying and secure relationships with others (ibid.). When these needs are satisfied, humans are self-determined, and this feeling of self-determination reinforces job satisfaction (Deci $e t$ $a l .$, 1989). The causal link between the satisfaction of these human needs at the workplace and employees' job satisfaction has already been shown by several studies (e.g. recently, Battaglio et al., 2021). This paper argues that these needs can be satisfied by job-related knowledge sharing and the availability of information. Access to relevant information is an essential prerequisite for earning expertise in handling a task. Accordingly, information serves to satisfy the need for competence. Information can serve as a support for autonomy at work as well (Vallerand et al., 2008), as sufficient information enables employees to handle their tasks autonomously. As Laschinger et al. (2001) put it, having access to information is an empowering structure that leads to feelings of autonomy and self-efficacy.

However, we doubt that there is a direct relationship between knowledge sharing by the knowledge donator and job satisfaction by the receiver, because knowledge can be useless, irrelevant or overloading and, therefore, fail to satisfy needs for competence and autonomy. Additonally, as Rhee and Choi (2017) illustrated, shared knowledge can be manipulated, leading to misguided and incorrect decisions and behaviour and, therefore, dissatisfaction. Especially in public organizations, there is a lack of appropriate storage or technical transfer of knowledge (Singh Sandhu et al., 2011). Thus, even if relevant knowledge is 
shared, it potentially cannot be received, accessed, or used by others. We suggest that only successful knowledge sharing, resulting in increasing job-relevant information availability, positively affects the job satisfaction of other employees.

Last but not least, the authors argue that seeking knowledge in a knowledge sharing interaction might be more challenging for information receivers compared to simply using available information that has already been shared, because knowledge seeking may be related to feelings of incompetence and dependency (Gubbins and Dooley, 2021). To ask someone for help or to receive information directly from a co-worker might cause more negative feelings than autonomously looking up information, for example, in a repositiory. Hence, knowledge sharing in interactions might even cause dissatifaction on the receiver's end. Accordingly, the following hypothesis will be tested:

(H1) The positive effect of job-related knowledge sharing on job satisfaction is mediated by the availability of job-relevant information.

In Figure 1, this mediation model is outlined.

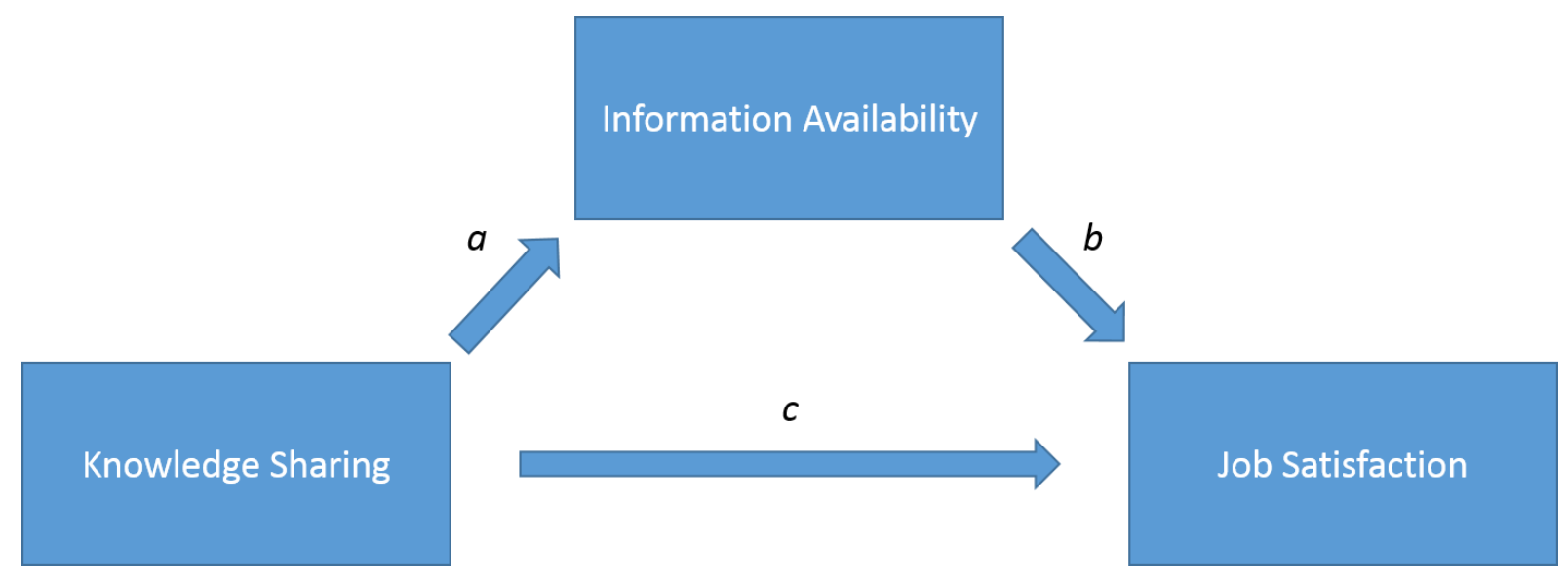

Figure 1: Basic mediation model examined in this study. 
Hypothesis 1 builds on two further sub-hypotheses. First, knowledge sharing increases the availability of information. While this may seem obvious, the authors again refrain from taking this causation for granted, as discussed above. The more knowledge is shared, the more information becomes available in an organization. However, only when relevant knowledge is shared to the needed extent and in a timely manner does relevant information become actually available to others. Thus, according to the 'intellectual capital method' (Stewart, 1998), availability of information could be treated as a result of successful knowledge management (Smits and Moor, 2004). Accordingly, the following hypothesis has to be tested:

(H2) The higher the intensity of job-related knowledge sharing between employees in an organization, the higher the amount of available job-relevant information in this organization.

Secondly, information availability has a positive impact on job satisfaction, which can be explained by self-determination theory (S-DT). As stated above, we argue that the need for competence and autonomy can be satisfied by the availability of job-relevant information and thereby increase job satisfaction. Bontis et al. (2011) found that job autonomy and employees' satisfaction are highly correlated. Additionally, Laschinger et al. (2001, p. 78) show that access to information is related to trust in management and, for this reason, to job satisfaction. They argue that employees trust managers more if they are willing to share accurate information in a timely fashion. Accordingly, the following hypothesis is tested:

(H3) The higher the amount of available job-relevant information in an organization, the higher the job satisfaction of this organization's employees. 


\section{METHOD AND RESULTS}

To test the presented model, data from the 2018 Federal Viewpoint Survey is used. The FEVS is one of the most comprehensive datasets available in public administration research and is widely used for a variety of different research interests (for an overview: Fernandez et $a l ., 2015)$. Various studies have utilized the FEVS dataset to examine, for example, risk aversion (Nicholson-Crotty et al., 2017), empowerment (Fernandez and Moldogaziev, 2015), or leadership (Asencio and Sun, 2019). The FEVS allows for testing public sector-specific models with data across different types of organizations.

The survey was conducted by the U.S. Office of Personnel Management (OPM). In 2018, the OPM received responses from 598,003 employees of the U.S. Federal Government. Most survey items are constructed as five-point Likert scales. Detailed information on the operationalization of variables is given in Appendix A.

Dependent variable: To measure job satisfaction, we construct an unweighted mean index comprised of three items evaluating employees' general satisfaction with their job and organization (Cronbach's $\alpha=0.91$ ). We build on the operationalization from Fernandez and Moldogaziev (2015) and include an item on recommending one's job to others, as is common practice in organizational psychology (e.g., Quinn and Staines, 1979).

Mediator variable: The suggested mediator job-related information availability (Cronbach's $\alpha=0.74$ ) is constructed as an unweighted mean index consisting of three items evaluating the individual and organizational availability of necessary information and knowledge. These items cover the assessment of information availability from various sources and at various organizational levels. Furthermore, the items differentiate between task-related, job-relevant, and organizational information. Thus, the index covers similar attempts to operationalize information availability from other management studies that measure the 
amount of available information (O'Reilly, 1980) as well as timely accessibility in order to secure the level of performance (Leidner and Elam, 1995).

Independent variable: As for the primary variable of interest, we use job-related knowledge sharing as operationalized by Kim and Ko (2014). This operationalization covers both aspects of knowledge sharing: the co-operative environment necessary for purposeful knowledge sharing and the actual dissemination of knowledge (Choi, 2015). While cooperation covers a wide range of activities aside from knowledge sharing, it is fundamental for healthy knowledge networks within teams and organizations. Furthermore, by following Kim and Ko (2014), we ensure comparability across studies using the FEVS. Both Cronbach's alpha $(\alpha=0.75)$ and the inter-item correlation (see Appendix B) are sufficient in the face of convergent validity.

Control variables: To support the validity of the model, we control for variables that might distort the mediation. Unreasonable workload may directly impede employees' ability to gather necessary information. Simultaneously, workload-related stress directly affects job satisfaction (Bond and Bunce, 2003). The educational level of the employee may also confound the effect on job satisfaction (Vallerand et al., 2008). Kianto et al. (2016) found evidence that the organizational position can influence the effect of knowledge sharing behaviour. Therefore, we control for a supervisory position. Finally, a variable to evaluate workplace training is added, which may affect the model because training is a source of information and might satisfy a need for learning (e.g. Schmidt, 2007).

Table 1 gives a short overview of the descriptive statistics of all variables used in our analysis. 
Table 1: Descriptive statistics of variables used in this study

\begin{tabular}{l|rrrrr}
\hline \multicolumn{1}{c|}{ Variable } & $\begin{array}{c}\text { Number of } \\
\text { Observations }\end{array}$ & \multicolumn{1}{c}{ Mean } & Std. Dev. & Min & Max \\
\hline Job satisfaction & 571,614 & 3.69 & 1.001 & 1 & 5 \\
Information availability & 568,575 & 3.73 & .832 & 1 & 5 \\
Knowledge sharing & 591,161 & 3.93 & 0.90 & 1 & 5 \\
Workplace training & 576,705 & 3.46 & 1.126 & 1 & 5 \\
Workload & 592,960 & 3.36 & 1.182 & 1 & 5 \\
Supervisor & 534,041 & .19 & .392 & 0 & 1 \\
Educational level & 520,623 & 2.08 & .802 & 1 & 3 \\
Woman & 518,903 & .44 & .496 & 0 & 1 \\
\hline
\end{tabular}

The statistical power provided by the dataset offers generalizable results. However, when using such large-n datasets, one should not focus solely on statistical significance but on effect sizes as well.

\section{Mediation analysis}

There are different ways to test for mediation effects (Preacher and Hayes, 2008): the causalsteps strategy (Baron and Kenny, 1986) and the product-of-coefficients approach (Sobel, 1982). With regard to the nature of the sample, this study considers both approaches.

The datasets include different organizational tiers: the agency, sub-agencies, and potential organizations two levels below the agency level. Problems due to the multi-level structure of the data may occur, which is why we conduct a mediation analysis for multi-level data using the Stata package $m l \_m e d i a t i o n$. The procedure is based on mixed-effects Restricted Maximum Likelihood Estimation regression. An essential assumption of this method is that the mediator variable should be at a level equal to or lower than that of the predictor (Krull and MacKinnon, 2001). This assumption is confirmed, although it is arguable whether the predictor (knowledge sharing) and the mediator (information availability) can be considered to be in the same tier in the dataset. However, the coefficients and p-values differ only marginally from normal OLS 
results as described below. Accounting for the multi-level bias, standard errors are clustered at the level of the agency, as the 2018 version only offers that data. Neither subsamples nor sampling weights were used in this analysis.

To calculate the mediation statistics, the sgmediation Stata package is used. Three OLS regressions are calculated following the causal-steps strategy. Table 2 gives the results.

Table 2: Results of OLS analysis

\begin{tabular}{|c|c|c|c|}
\hline & $\begin{array}{l}\text { (1) } \\
\text { Information } \\
\text { Availability }\end{array}$ & $\begin{array}{c}\text { (2) } \\
\text { Job } \\
\text { Satisfaction }\end{array}$ & $\begin{array}{c}(3) \\
\text { Job } \\
\text { Satisfaction }\end{array}$ \\
\hline Knowledge sharing & $\begin{array}{c}0.328 * * * \\
(0.005)\end{array}$ & $\begin{array}{c}0.332 * * * \\
(0.009)\end{array}$ & $\begin{array}{c}0.137 * * * \\
(0.007)\end{array}$ \\
\hline Workplace training & $\begin{array}{c}0.304 * * * \\
(0.004)\end{array}$ & $\begin{array}{c}0.348 * * * \\
(0.004)\end{array}$ & $\begin{array}{c}0.167 * * * \\
(0.003)\end{array}$ \\
\hline Workload & $\begin{array}{c}-0.146 * * * \\
(0.003)\end{array}$ & $\begin{array}{c}-0.195^{* * *} * \\
(0.007)\end{array}$ & $\begin{array}{c}-0.108 * * * \\
(0.005)\end{array}$ \\
\hline Supervisor & $\begin{array}{c}0.092 * * * \\
(0.012)\end{array}$ & $\begin{array}{c}0.101 * * * \\
(0.010)\end{array}$ & $\begin{array}{c}0.046^{* * * *} \\
(0.006)\end{array}$ \\
\hline Education level & $\begin{array}{l}-0.008 \\
(0.006)\end{array}$ & $\begin{array}{l}-0.016 \\
(0.014)\end{array}$ & $\begin{array}{l}-0.011 \\
(0.011)\end{array}$ \\
\hline Woman & $\begin{array}{c}0.016 \\
(0.009)\end{array}$ & $\begin{array}{c}0.042 * * \\
(0.016)\end{array}$ & $\begin{array}{c}0.032 * * * \\
(0.011)\end{array}$ \\
\hline $\begin{array}{l}\text { Information } \\
\text { availability }\end{array}$ & & & $\begin{array}{c}0.594 * * * \\
(0.007)\end{array}$ \\
\hline _cons & $\begin{array}{c}1.755^{* * * *} \\
(0.037)\end{array}$ & $\begin{array}{c}1.696^{* * * *} \\
(0.056)\end{array}$ & $\begin{array}{c}0.654 * * * \\
(0.047)\end{array}$ \\
\hline$N$ & 492,289 & 492,289 & 492,289 \\
\hline$R^{2}$ & $\begin{array}{l}0.584 \\
0.584\end{array}$ & $\begin{array}{l}0.515 \\
0.515\end{array}$ & $\begin{array}{l}0.617 \\
0617\end{array}$ \\
\hline
\end{tabular}

Standard errors in parentheses, standard errors clustered at agency level $* p<0.05, * * p<0.01, * * * p<0.001$ 
The first model describes path a, the second path c, and the last model shows the results for both paths $b$ and $c^{\prime}$ (see Figure 1). All three models have a decent model fit ranging from 0.52 to $0.62\left(\mathrm{R}^{2}\right)$. Starting with path a, knowledge sharing increases the availability of job-related information as expected, with a significant coefficient of about 0.328 (model 1). Simultaneously, knowledge sharing increases job satisfaction $(\beta=0.33$ in model 2$)$. This effect is considerably decreased by about $59 \%(\beta=0.137$ in model 3$)$ when the mediator is introduced into the regression. Though this is not a full mediation, the mediation effect is still remarkable. The same model shows a comparably strong positive and significant effect of job-related information availability $(\beta=0.594)$ on job satisfaction while controlling for knowledge sharing.

The results also show a substantial positive effect of training and a negative effect of an unreasonable workload. The supervisory status of respondents has a positive effect on information availability and job satisfaction. One explanation could be that supervisors often have a longer tenure, making it easier for them to accumulate knowledge. Additionally, supervisors often have direct access to information from higher tiers of the hierarchy. They function as a multiplier for subordinate teams regarding such information. However, the effect sizes are rather small and should not be overrated, especially considering that the vast number of observations leads to significant results even for minor effects. Most other control variables such as gender and education have negligible effect sizes as well. This may be due to the rather crude operationalization of latter two within the FEVS.

Table 3 shows the properties of the mediation in the explained model. 
Table 3: Mediation-specific statistics for the full mediation model

\begin{tabular}{l|llll} 
& Coefficient & Std. Err. & $\mathrm{Z}$ & $\mathrm{P}>\mathrm{Z}$ \\
\hline Indirect effect & .195 & .001 & 338.129 & $>.001$ \\
Direct effect & .137 & .001 & 110.712 & $>.001$ \\
Total effect & .332 & .001 & 264.199 & $>.001$
\end{tabular}

Proportion of total effect that is mediated: $\mid .587$

The proportion of the mediated effect is quite considerable. The Sobel test results (productof-coefficients approach) are highly significant. The null hypothesis, stating that there is no effect on job satisfaction mediated by the availability of job-related information, can be rejected with certainty for this dataset. Additionally, the Completely Standardized Indirect Effect $\left(a b_{c s}\right)$, as suggested by Preacher and Kelley (2011), is calculated to evaluate the actual effect size of the mediation model. The mediation model achieves an $a b_{c s}=0.195$. This can be interpreted as a medium-sized effect (Gordon et al., 2013, p. 640).

In addition, the mediation model is replicated in prior waves of the FEVS dataset ${ }^{1}$. However, the FEVS is not a panel dataset. Although the dataset can be analyzed longitudinally when working on the agency or sub-agency level, as demonstrated by Oberfield (2014), for example, each wave can only be analyzed cross-sectionally when the individual level is taken into consideration. Yet, to use the potential of a yearly replicated data selection anyway, we decided to replicate our analysis in former waves of the FEVS. As can be seen in the trend analysis in Figure 2, both the size of the indirect effect and the proportion of the total effect being mediated remain rather stable over the years. This stability serves as an indicator of the reliability of the presented mediation model.

1 Due to data availability, educational level was excluded from this comparison. 


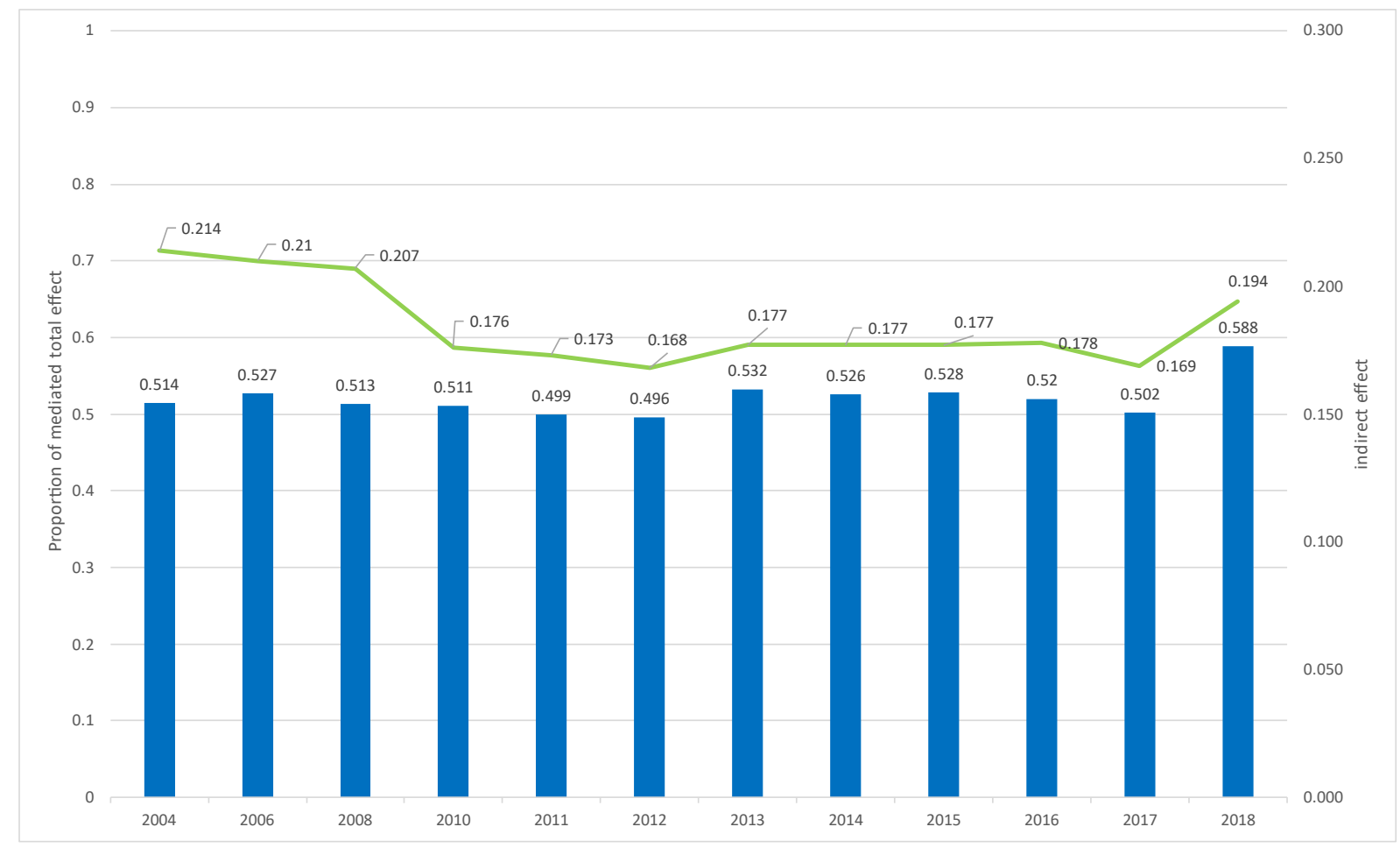

Figure 2: Mediation properties over time (2004-2018); the line indicates the size of the indirect effect, bars indicate the proportion of the total effect that is mediated through information availability; FEVS trend data.

\section{DISCUSSION}

As shown by the results of the statistical analysis, the central hypothesis (H1) is supported by the data. A considerable part of the effect of knowledge sharing on job satisfaction is mediated by the availability of necessary information. If knowledge management succeeds in providing easily accessible and purposeful information for employees, it may foster positive effects on other outcomes like job satisfaction. These results point to the design implications of repositories, such as databases, document management systems, or wikis. These have to be user-friendly to make information actually available instead of just stored, and employees have to be trained in using them.

Overall, the results support the assumptions of self-determination theory. Autonomy and competence can be fostered by supplying employees with the needed information and, as a consequence, increase their motivation and satisfaction. 
This is in line with other findings on the determinants of job satisfaction. In a two-wave panel study, for instance, Bond and Bunce (2003) found that higher job control levels predict higher job satisfaction. The availability of information increases these levels of job control. Pick and Teo (2016) studied public middle managers in processes of change and showed that providing change information can reduce stressors and promote job satisfaction. They therefore use the term 'need for information' (p. 717). Besides this positive effect of autonomy on job satisfaction, in a two-wave panel study, Agho et al. (1993, p. 1019) found that missing information needed to perform tasks adequately has a negative influence on job satisfaction. The results of this study are also in line with findings with regard to information receivers and users in virtual communities and online knowledge sharing. Nguyen et al. (2021) show that the majority of information receivers value self-enjoyment in the online knowledge-sharing process and thus the satisfaction of their own needs.

However, the analysis reveals a partial mediation only. Knowledge sharing itself seems to have an impact on job satisfaction. This may be explained by another basic human need, also outlined in self-determination theory but widely underestimated in knowledge management research: relatedness. The interactive behaviour of knowledge sharing carried out by colleagues can satisfy this need. The results support the assumption that the satisfaction of relatedness is crucial for internalizing the motivation derived from satisfying the need for autonomy (Gagné and Deci, 2005, p. 337). Thus, support of autonomy and competence is enhanced in the context of relatedness. Irrespective of the focus on knowledge sharing, other studies have revealed similar results for work-based support, which is a critical resource for strengthening well-being and job satisfaction (e.g. Noblet and Rodwell, 2009).

The social interaction involved in sharing one's knowledge within a team may improve relations by strengthening mutual appreciation and trust (Baek et al., 2017). Therefore, knowledge sharing may create a culture of teamwork. The positive effects of such co-operative working patterns in teams have been observed in numerous studies (e.g., Glisson and James, 
2002) and do in turn influence knowledge sharing behaviour of team members (Vashdi, 2013). That was also found by Yu and Takahashi (2021), for example, who show that human resource practices that enhance trust among coworkers and between employees and supervisors positively influence knowledge-sharing behaviour. Simultaneously, Kianto et al. (2016) argue that knowledge sharing fosters job satisfaction because knowledge donators experience a feeling of being valuable and important to their colleagues and organization. Hence, social interaction in knowledge sharing seems to create a cycle of trust and reciprocity (Fischer, 2021; Haesebrouck et al., 2021).

Hartley and Allison (2002) came to a similar conclusion in their study on an interorganizational network in the UK's public sector: not only sharing of information was valued by participants in the network, but also "interactivity with participants and discussions" (p. 111) and "gaining new contacts" (p. 109). The importance of social interaction might be typical for the public sector, as government executives consider their colleagues as more crucial than their private sector counterparts (Posner and Schmidt, 1996). In that regard, Brown et al. (2013) showed that social interaction can be used to bypass insufficient formal knowledge management systems. They found that employees tend to avoid knowledge management systems and value personal interaction in knowledge sharing even when there is codified knowledge available (Brown et al., 2013, p. 2020).

The results of this study also emphasize the value of self-determination theory in comparison to rather classic work design theories, such as Hackman and Oldham (1980) or Lawler and Hall (1970), that propose a significant increase in performance based on more autonomous forms of work design but oversee the influence of co-workers and social factors. Self-determination theory is better at capturing this boader picture of autonomy, competence, and relatedness and, therefore, adds significant theoretical value. 


\section{CONCLUSION}

This paper investigates the effect of knowledge sharing on job satisfaction mediated via the availability of job-related information. The results confirm a partial mediation and a significantly positive relationship. Employees sharing their knowledge can notably increase the available relevant information for their colleagues. This again increases the job satisfaction of individual employees by satisfying basic needs for autonomy and competence. However, job satisfaction also partly results from the act of knowledge sharing itself. This shows the importance of the need for relatedness and social interactions.

This study particularly contributes to the nascent literature on public sector knowledge management. As research has been focusing on determinants of knowledge sharing so far, this article uses knowledge sharing as an independent variable and, furthermore, job satisfaction is analysed as an outcome of this behaviour. Thereby, knowledge sharing as a behaviour is separated from information availability as an output of this behaviour. Both constructs explain job satisfaction of public employees. For future research, this separation of constructs may prevent inconsistent results concerning the determinants of public employees' knowledge sharing.

This article offers three contributions to research on knowledge sharing. First, this study sheds light on the causal relationship between knowledge sharing and job satisfaction. Knowledge sharing serves as a significant source of job-related information availability. This pool of informational resources then enables workers to handle the required tasks and leaves them satisfied. Second, a psychological framework is offered that is useful for understanding the effects of knowledge management. Self-determination theory helps to conceptualize the effects of knowledge sharing and information availability. It is shown that the interaction of the needs for autonomy and competence on the one hand and the need for relatedness on the other offers a rich source of explanation and distinguishes this theory from other organizational 
theories. Third, we confirm the proposed model by analysing a major dataset from the U.S. federal administration (FEVS) over several waves. These very stable results indicate high reliability.

Naturally, this study comes with several limitations. First, the causal direction of knowledge sharing behaviour is contestable. Vries et al. (2006) found evidence for job satisfaction facilitating knowledge sharing. Cross-sectional studies are not able to solve this problem, however. Nevertheless, a reverse causal direction is highly unlikely in the proposed model because one's job satisfaction does not directly affect others' knowledge sharing behaviour. Second, although the FEVS offers a rich and comprehensive source for data, various risks of misuse have been emphasized (e.g., Fernandez et al., 2015; Resh et al., 2019). Accordingly, we aimed to offer a transparent and comprehensible approach to our analysis.

In addition to the above, the datasets themselves come with several limitations. Most notably, due to the nature of secondary data, we need to acknowledge the trade-off between the strength of the dataset's size and the restrictions in the variable use. Therefore, we suggest that future research should try to replicate the results of this study with more elaborated scales for measuring both sharing behaviour and information availability.

Furthermore, due to the measurement, it is not possible to differentiate between direct (with other people) or indirect knowledge sharing (with a medium). However, this could be especially interesting when comparing public and private organizations. Bureaucratic structures could enhance an organizational preference for technical solutions and exacerbate the use of indirect knowledge sharing while inhibiting direct knowledge sharing due to hierarchy and stricter organizational divides.

However, as it was found here that interaction fosters job satisfaction, direct knowledge sharing should be fostered. This may, for example, happen in frequent meetings and talks among colleagues, as well as between employees and supervisors. The consequence of ignoring such needs can otherwise cause dissatisfaction. The observed importance of social interaction 
calls for more direct interactive knowledge sharing activities than the mere reliance on knowledge repositories. Hence, knowledge management should not only rely on technical solutions that transfer information. It should instead offer people the opportunity to interact with one another. Aside from coffee-break chats and team-meetings, this could take place, for example, in workshops of knowledge transfer, the so-called 'knowledge-relay' before retirements or job rotations. Knowledge management based on social interaction in this way is especially contested in times of increasing use of telework and mobile work settings. Teams working from home or in different offices should find ways to interact digitally, in formal as well as informal ways. Discussion forums, wikis, chats, messenger services or video conferences can serve as digital channels for such an interaction-based knowledge sharing. 


\section{REFERENCES}

Agho, A.O., Mueller, C.W. and Price, J.L. (1993), "Determinants of Employee Job Satisfaction. An Empirical Test of a Causal Model", Human Relations, Vol. 46 No. 8, pp. 1007-1027.

Ahmad, F. and Karim, M. (2019), "Impacts of knowledge sharing: a review and directions for future research", Journal of Workplace Learning, Vol. 31 No. 3, pp. 207-230.

Andreeva, T. and Kianto, A. (2012), "Does knowledge management really matter? Linking knowledge management practices, competitiveness and economic performance”, Journal of Knowledge Management, Vol. 16 No. 4, pp. 617-636.

Asencio, H.D. and Sun, R. (2019), "The Effects of Leadership on Employee Trust: A Longitudinal Study of United States Federal Agencies", International Journal of Public Administration, Vol. 7, pp. 1-15.

Baek, E.C., Scholz, C., O'Donnell, M.B. and Falk, E.B. (2017), "The Value of Sharing Information. A Neural Account of Information Transmission”, Psychological Science, Vol. 28 No. 7, pp. 851-861.

Baron, R.M. and Kenny, D.A. (1986), "The moderator-mediator variable distinction in social psychological research. Conceptual, strategic, and statistical considerations", Journal of Personality and Social Psychology, Vol. 51 No. 6, pp. 1173-1182.

Battaglio, R.P., Belle, N. and Cantarelli, P. (2021), "Self-determination theory goes public: experimental evidence on the causal relationship between psychological needs and job satisfaction", Public Management Review, pp. 1-18.

Bond, F.W. and Bunce, D. (2003), "The role of acceptance and job control in mental health, job satisfaction, and work performance", The Journal of Applied Psychology, Vol. 88 No. 6, pp. 1057-1067.

Bontis, N., Richards, D. and Serenko, A. (2011), "Improving service delivery. Investigating the role of information sharing, job characteristics, and employee satisfaction", The Learning Organization, Vol. 18 No. 3, pp. 239-250.

Brown, S.A., Dennis, A.R., Burley, D. and Arling, P. (2013), "Knowledge sharing and knowledge management system avoidance. The role of knowledge type and the social network in bypassing an organizational knowledge management system", Journal of the American Society for Information Science and Technology, Vol. 64 No. 10, pp. 20132023.

Choi, Y. (2015), “The Impact of Social Capital on Employees' Knowledge-Sharing Behavior. An Empirical Analysis of U.S. Federal Agencies", Public Performance \& Management Review, Vol. 39 No. 2, pp. 381-405.

Chordiya, R., Sabharwal, M. and Goodman, D. (2017), “Affective organizational commitment and job satisfaction. a cross-national comparative study", Public Administration, Vol. 95 No. 1, pp. 178-195.

Colnar, S. and Dimovski, V. (2017), "Knowledge management initiatives benefits for the Slovenian public sector", Management: journal of contemporary management issues, Vol. 22 No. Special Issue, pp. 145-161.

Cuganesan, S., Hart, A. and Steele, C. (2016), "Managing information sharing and stewardship for public-sector collaboration. A management control approach", Public Management Review, Vol. 19 No. 6, pp. 862-879.

Deci, E.L., Connell, J.P. and Ryan, R.M. (1989), "Self-determination in a work organization", Journal of Applied Psychology, Vol. 74 No. 4, pp. 580-590. 
Deci, E.L. and Ryan, R.M. (2008), "Self-determination theory. A macrotheory of human motivation, development, and health", Canadian Psychology/Psychologie canadienne, Vol. 49 No. 3, pp. 182-185.

Deci, E.L. and Vansteenkiste, M. (2004), "Self-determination theory and basic need satisfaction: Understanding human development in positive psychology", Ricerche di Psicologia, Vol. 27 No. 1, pp. 23-40.

Eldor, L. (2018), "Public Service Sector. The Compassionate Workplace-The Effect of Compassion and Stress on Employee Engagement, Burnout, and Performance", Journal of Public Administration Research and Theory, Vol. 28 No. 1, pp. 86-103.

Fernandez, S. and Moldogaziev, T. (2015), "Employee Empowerment and Job Satisfaction in the U.S. Federal Bureaucracy", The American Review of Public Administration, Vol. 45 No. 4, pp. 375-401.

Fernandez, S., Resh, W.G., Moldogaziev, T. and Oberfield, Z.W. (2015), “Assessing the Past and Promise of the Federal Employee Viewpoint Survey for Public Management Research. A Research Synthesis”, Public Administration Review, Vol. 75 No. 3, pp. 382 394.

Fischer, C. (2021), “Incentives Can’t Buy Me Knowledge: The Missing Effects of Appreciation and Aligned Performance Appraisals on Knowledge Sharing of Public Employees", Review of Public Personnel Administration, Vol. 78 No. 2.

Fisher, G.G., Matthews, R.A. and Gibbons, A.M. (2016), "Developing and investigating the use of single-item measures in organizational research", Journal of Occupational Health Psychology, Vol. 21 No. 1, pp. 3-23.

Gagné, M. and Deci, E.L. (2005), "Self-determination theory and work motivation", Journal of Organizational Behavior, Vol. 26 No. 4, pp. 331-362.

Glisson, C. and James, L.R. (2002), "The cross-level effects of culture and climate in human service teams", Journal of Organizational Behavior, Vol. 23 No. 6, pp. 767-794.

Gordon, A.M., Tuskeviciute, R. and Chen, S. (2013), "A multimethod investigation of depressive symptoms, perceived understanding, and relationship quality", Personal Relationships, Vol. 20 No. 4, pp. 635-654.

Gruneberg, M.M. (1979), Understanding job satisfaction, Wiley, New York.

Gubbins, C. and Dooley, L. (2021), "Delineating the tacit knowledge-seeking phase of knowledge sharing: The influence of relational social capital components", Human Resource Development Quarterly, Vol. 47 No. 6, p. 795.

Hackman, J.R. and Oldham, G.R. (1980), Work redesign, Addison-Wesley series on organization development, Addison-Wesley, Reading, Mass.

Haesebrouck, K., van den Abbeele, A. and Williamson, M.G. (2021), "Building trust through knowledge sharing: Implications for incentive system design", Accounting, Organizations and Society, Vol. 17 No. 4, p. 101241.

Hartley, J. and Allison, M. (2002), "Good, Better, Best? Inter-organizational learning in a network of local authorities", Public Management Review, Vol. 4 No. 1, pp. 101-118.

Henttonen, K., Kianto, A. and Ritala, P. (2016), "Knowledge sharing and individual work performance. An empirical study of a public sector organisation", Journal of Knowledge Management, Vol. 20 No. 4, pp. 749-768.

Holsapple, C.W., Hsiao, S.-H. and Oh, J.-Y. (2016), "Parameters of knowledge management success", in Liebowitz, J. (Ed.), Successes and failures of knowledge management, Elsevier, Cambridge, pp. 1-12. 
Hsieh, J.Y. (2016), "Spurious or True? An Exploration of Antecedents and Simultaneity of Job Performance and Job Satisfaction Across the Sectors", Public Personnel Management, Vol. 45 No. 1, pp. 90-118.

Ipe, M. (2003), "Knowledge Sharing in Organizations. A Conceptual Framework”, Human Resource Development Review, Vol. 2 No. 4, pp. 337-359.

Judge, T.A., Zhang, S.C. and Glerum, D.R. (2020), "Job satisfaction”, Essentials of Job Attitudes and Other Workplace Psychological Constructs, pp. 207-241.

Kianto, A., Vanhala, M. and Heilmann, P. (2016), "The impact of knowledge management on job satisfaction", Journal of Knowledge Management, Vol. 20 No. 4, pp. 621-636.

Kim, S. and Lee, H. (2006), "The Impact of Organizational Context and Information Technology on Employee Knowledge-Sharing Capabilities”, Public Administration Review, Vol. 66 No. 3, pp. 370-385.

Kim, Y.W. and Ko, J. (2014), "HR Practices and Knowledge Sharing Behavior", Public Personnel Management, Vol. 43 No. 4, pp. 586-607.

Krull, J.L. and MacKinnon, D.P. (2001), "Multilevel Modeling of Individual and Group Level Mediated Effects”, Multivariate Behavioral Research, Vol. 36 No. 2, pp. 249-277.

Laschinger, H.K., Finegan, J. and Shamian, J. (2001), "The impact of workplace empowerment, organizational trust on staff nurses' work satisfaction and organizational commitment", Health care management review, Vol. 26 No. 3, pp. 59-85.

Law, C.C.H. and Ngai, E.W.T. (2008), "An empirical study of the effects of knowledge sharing and learning behaviors on firm performance", Expert Systems with Applications, Vol. 34 No. 4, pp. 2342-2349.

Lawler, E.E. and Hall, D.T. (1970), "Relationship of job characteristics to job involvement, satisfaction, and intrinsic motivation”, Journal of Applied Psychology, Vol. 54 No. 4, pp. 305-312.

Leidner, D.E. and Elam, J.J. (1995), "The Impact of Executive Information Systems on Organizational Design, Intelligence, and Decision Making”, Organization Science, Vol. 6 No. 6, pp. 645-664.

Moffett, S. and McAdam, R. (2009), "Knowledge management. A factor analysis of sector effects", Journal of Knowledge Management, Vol. 13 No. 3, pp. 44-59.

Nguyen, M., Malik, A. and Sharma, P. (2021), "How to motivate employees to engage in online knowledge sharing? Differences between posters and lurkers", Journal of Knowledge Management, Vol. 25 No. 7, pp. 1811-1831.

Nicholson-Crotty, S., Nicholson-Crotty, J. and Fernandez, S. (2017), "Performance and Management in the Public Sector: Testing a Model of Relative Risk Aversion", Public Administration Review, Vol. 77 No. 4, pp. 603-614.

Noblet, A.J. and Rodwell, J.J. (2009), "Identifying the Predictors of Employee Health and Satisfaction in an Npm Environment", Public Management Review, Vol. 11 No. 5, pp. 663-683.

Nonaka, I. and Takeuchi, H. (1995), The knowledge-creating company: How Japanese companies create the dynamics of innovation, Oxford University Press, New York.

Oberfield, Z.W. (2014), "Public Management in Time: A Longitudinal Examination of the Full Range of Leadership Theory", Journal of Public Administration Research and Theory, Vol. 24 No. 2, pp. 407-429.

O'Reilly, C.A. (1980), "Individuals and Information Overload in Organizations: Is More Necessarily Better?”, Academy of Management Journal, Vol. 23 No. 4, pp. 684-696. 
Paulin, D. and Suneson, K. (2015), "Knowledge Transfer, Knowledge Sharing and Knowledge Barriers - Three Blurry Terms in KM", in Grant, K.A. and Dumay, J. (Eds.), Leading Issues in Knowledge Management, Academic Conferences and Publishing International, Reading, pp. 73-94.

Pick, D. and Teo, S.T.T. (2016), "Job satisfaction of public sector middle managers in the process of NPM change”, Public Management Review, Vol. 19 No. 5, pp. 705-724.

Posner, B.Z. and Schmidt, W.H. (1996), "The Values of Business and Federal Government Executives. More Different Than Alike”, Personnel Administration, Vol. 25 No. 3, pp. 277-289.

Preacher, K.J. and Hayes, A.F. (2008), “Asymptotic and resampling strategies for assessing and comparing indirect effects in multiple mediator models", Behavior Research Methods, Vol. 40 No. 3, pp. 879-891.

Preacher, K.J. and Kelley, K. (2011), "Effect size measures for mediation models. Quantitative strategies for communicating indirect effects", Psychological Methods, Vol. 16 No. 2, pp. 93-115.

Quinn, R.P. and Staines, G. (1979), Quality of Employment Survey, 1977: Cross-Section, Inter-university Consortium for Political and Social Research, University of Michigan, Ann Arbor.

Rainey, H.G. (2010), Understanding and managing public organizations, Jossey-Bass, San Francisco.

Rashman, L., Withers, E. and Hartley, J. (2009), "Organizational learning and knowledge in public service organizations. A systematic review of the literature", International Journal of Management Reviews, Vol. 11 No. 4, pp. 463-494.

Resh, W., Moldogaziev, T., Fernandez, S. and Leslie, C.A. (2019), "Reversing the Lens: Assessing the Use of Federal Employee Viewpoint Survey in Public Administration Research", Review of Public Personnel Administration, Vol. 77 No. 1, $0734371 X 1986501$.

Rhee, Y.W. and Choi, J.N. (2017), "Knowledge management behavior and individual creativity. Goal orientations as antecedents and in-group social status as moderating contingency", Journal of Organizational Behavior, Vol. 38, pp. 813-832.

Schmidt, S.W. (2007), "The relationship between satisfaction with workplace training and overall job satisfaction", Human Resource Development Quarterly, Vol. 18 No. 4, pp. 481-498.

Singh Sandhu, M., Kishore Jain, K. and Umi Kalthom bte Ahmad, I. (2011), "Knowledge sharing among public sector employees. Evidence from Malaysia", International Journal of Public Sector Management, Vol. 24 No. 3, pp. 206-226.

Smits, M. and Moor, A. de (2004), "Effective knowledge management in knowledgeintensive organizations", Proceedings of Organizational Knowledge, Learning and Capabilities, pp. 1-10.

Sobel, M.E. (1982), “Asymptotic Confidence Intervals for Indirect Effects in Structural Equation Models", Sociological Methodology, Vol. 13, p. 290.

Stewart, T.A. (1998), Intellectual capital: The new wealth of organizations, Cown Business, New York [etc.].

Vallerand, R.J., Pelletier, L.G. and Koestner, R. (2008), "Reflections on self-determination theory”, Canadian Psychology/Psychologie canadienne, Vol. 49 No. 3, pp. 257-262. 
Vashdi, D.R. (2013), "Teams in Public Administration: A Field Study of Team Feedback and Effectiveness in the Israeli Public Healthcare System", International Public Management Journal, Vol. 16 No. 2, pp. 275-306.

Vries, R.E. de, van den Hooff, B. and Ridder, J.A. de (2006), "Explaining Knowledge Sharing", Communication Research, Vol. 33 No. 2, pp. 115-135.

Willem, A. and Buelens, M. (2006), "Knowledge Sharing in Public Sector Organizations. The Effect of Organizational Characteristics on Interdepartmental Knowledge Sharing", Journal of Public Administration Research and Theory, Vol. 17 No. 4, pp. 581-606.

$\mathrm{Yu}, \mathrm{C}$., Yu, T.-F. and Yu, C.-C. (2013), "Knowledge Sharing, Organizational Climate, and Innovative Behavior. A Cross-Level Analysis of Effects", Social Behavior and Personality: an international journal, Vol. 41 No. 1, pp. 143-156.

$\mathrm{Yu}, \mathrm{H}$. and Takahashi, Y. (2021), "Knowledge-sharing mechanisms: human resource practices and trust", Journal of Organizational Effectiveness: People and Performance, Vol. 8 No. 2, pp. 173-189.

\section{Stata packages used}

sgmediation: Phil Ender, UCLA Statistical Consulting Group, ender@ucla.edu

ml_mediation: Phil Ender, UCLA Statistical Consulting Group, ender@ucla.edu 


\section{APPENDIX}

Appendix A: Operationalization of variables

\begin{tabular}{|c|c|c|c|}
\hline \multicolumn{2}{|c|}{ Variables } & Items & Scales \\
\hline \multicolumn{4}{|c|}{ Dependent Variable } \\
\hline \multirow{4}{*}{$\begin{array}{l}\text { Job } \\
\text { satisfaction } \\
(\alpha=.91)\end{array}$} & Jobsat1 & 'I recommend my organization & \multirow{3}{*}{$\begin{array}{l}\text { 5-point-Likert scale } \\
\text { (1=Strongly Disagree, } \\
\ldots \text { 5=Strongly Agree) }\end{array}$} \\
\hline & & & \\
\hline & Jobsat2 & $\begin{array}{l}\text { 'Considering everything, how } \\
\text { satisfied are you with your job?' } \\
\text { - Q69 }\end{array}$ & \\
\hline & Jobsat3 & $\begin{array}{l}\text { 'Considering everything, how } \\
\text { satisfied are you with your } \\
\text { organization?' - Q71 }\end{array}$ & $\begin{array}{l}\text { 5-point-Likert scale } \\
\text { (1=Very Dissatisfied, } \\
\text {.. 5=Very Satisfied) }\end{array}$ \\
\hline \multicolumn{4}{|c|}{ Mediator Variable } \\
\hline \multirow{3}{*}{$\begin{array}{l}\text { Information } \\
\text { availability } \\
(\alpha=.74)\end{array}$} & Infoavailability 1 & $\begin{array}{l}\text { 'I have enough information to do } \\
\text { my job well.' - Q2 }\end{array}$ & \multirow{3}{*}{$\begin{array}{l}\text { 5-point-Likert scale } \\
\text { (1=Strongly Disagree, } \\
\text {.. 5=Strongly Agree) } \\
\text { 5-point-Likert scale } \\
\text { (1=Very Dissatisfied, } \\
\text {... 5=Very Satisfied) }\end{array}$} \\
\hline & Infoavailability 2 & $\begin{array}{l}\text { 'The workforce has the job- } \\
\text { relevant knowledge and skills } \\
\text { necessary to accomplish } \\
\text { organizational goals.' - Q29 }\end{array}$ & \\
\hline & Infoavailability 3 & $\begin{array}{l}\text { 'How satisfied are you with the } \\
\text { information you receive from } \\
\text { management on what's going on } \\
\text { in your organization?' - Q64 }\end{array}$ & \\
\hline \multicolumn{4}{|c|}{ Independent Variable } \\
\hline \multirow[t]{2}{*}{$\begin{array}{l}\text { Knowledge } \\
\text { sharing } \\
(\alpha=.75)\end{array}$} & Knowshare1 & $\begin{array}{l}\text { 'The people I work with } \\
\text { cooperate to get the job done.' - } \\
\text { Q20 }\end{array}$ & \multirow[t]{2}{*}{$\begin{array}{l}\text { 5-point-Likert scale } \\
\text { (1=Strongly Disagree, } \\
\ldots 5=\text { Strongly Agree) }\end{array}$} \\
\hline & Knowshare2 & $\begin{array}{l}\text { 'Employees in my work unit } \\
\text { share job knowledge with each } \\
\text { other.' - Q26 }\end{array}$ & \\
\hline \multicolumn{4}{|c|}{ Control Variables } \\
\hline \multicolumn{2}{|c|}{ Workplace training } & $\begin{array}{l}\text { 'How satisfied are you with the } \\
\text { training you receive for your } \\
\text { present job?' - Q68 }\end{array}$ & $\begin{array}{l}\text { 5-point-Likert scale } \\
\text { (1=Very Dissatisfied, } \\
\ldots \text { 5=Very Satisfied) }\end{array}$ \\
\hline \multicolumn{2}{|c|}{ Workload (reversed) } & $\begin{array}{l}\text { 'My workload is reasonable.' - } \\
\text { Q10 }\end{array}$ & 5-point-Likert scale \\
\hline
\end{tabular}




\begin{tabular}{|l|l|l|}
\hline Supervisor & $\begin{array}{l}\text { (1=Strongly Agree, .. } \\
5=\text { Strongly Disagree })\end{array}$ \\
\hline Education level & $\begin{array}{l}\text { 'What is your supervisory } \\
\text { status?' - Q86 } \\
\text { supervisor } \\
0=\text { respondent is not a } \\
\text { supervisor }\end{array}$ \\
\hline Woman & $\begin{array}{l}\text { 'What is the highest degree or } \\
\text { level of education you have } \\
\text { completed?' }- \text { Q90 }\end{array}$ & $\begin{array}{l}\text { 1=Less than Bachelor's } \\
\text { Degree } \\
\text { 2=Bachelor's Degree } \\
3=\text { Post-Bachelor's } \\
\text { Degree }\end{array}$ \\
\hline & 'Are you:' - Q87 & $\begin{array}{l}1=\text { female respondent } \\
0=\text { male respondent }\end{array}$ \\
\hline
\end{tabular}

* Note: Q refers to the label in the FEVS survey. 
Appendix B: Means, standard deviations, and correlations with confidence intervals

\begin{tabular}{|c|c|c|c|c|c|c|c|c|c|c|c|c|c|c|}
\hline Variable & $M$ & $S D$ & 1 & 2 & 3 & 4 & 5 & 6 & 7 & 8 & 9 & 10 & 11 & 12 \\
\hline Knowshare1 & 3.97 & 1.00 & & & & & & & & & & & & \\
\hline Knowshare2 & 3.90 & 1.01 & $\begin{array}{l}.60 * * \\
{[.60, .60]}\end{array}$ & & & & & & & & & & & \\
\hline Infoavailability1 & 3.76 & 1.01 & $\begin{array}{l}.40 * * \\
{[.40, .40]}\end{array}$ & $\begin{array}{c}.41^{* *} \\
{[.40, .41]}\end{array}$ & & & & & & & & & & \\
\hline Infoavailability2 & 4.05 & 0.91 & $\begin{array}{l}.51 * * \\
{[.51, .52]}\end{array}$ & $\begin{array}{c}.49 * * \\
{[.49, .49]}\end{array}$ & $\begin{array}{l}.48^{* * *} \\
{[.48, .48]}\end{array}$ & & & & & & & & & \\
\hline Infoavailability3 & 3.35 & 1.15 & $\begin{array}{l}.41 * * \\
{[.41, .42]}\end{array}$ & $\begin{array}{c}.42 * * \\
{[.42, .42]}\end{array}$ & $\begin{array}{l}.54^{* *} \\
{[.54, .54]}\end{array}$ & $\begin{array}{l}.45^{* *} \\
{[.44, .45]}\end{array}$ & & & & & & & & \\
\hline Jobsat1 & 3.76 & 1.09 & $\begin{array}{l}.47 * * \\
{[.47, .48]}\end{array}$ & $\begin{array}{c}.45^{* *} \\
{[.45, .45]}\end{array}$ & $\begin{array}{c}.55^{* *} \\
{[.54, .55]}\end{array}$ & $\begin{array}{l}.51 * * \\
{[.51, .51]}\end{array}$ & $\begin{array}{l}.60^{* *} \\
{[.60, .61]}\end{array}$ & & & & & & & \\
\hline Jobsat2 & 3.75 & 1.07 & $\begin{array}{l}.45 * * \\
{[.45, .45]}\end{array}$ & $\begin{array}{c}.43^{* *} \\
{[.43, .43]}\end{array}$ & $\begin{array}{l}.56^{* *} \\
{[.56, .57]}\end{array}$ & $\begin{array}{l}.48 * * \\
{[.48, .49]}\end{array}$ & $\begin{array}{l}.60^{* *} \\
{[.60, .61]}\end{array}$ & $\begin{array}{l}.73^{* *} \\
{[.73, .73]}\end{array}$ & & & & & & \\
\hline Jobsat3 & 3.56 & 1.11 & $\begin{array}{l}.45 * * \\
{[.45, .45]}\end{array}$ & $\begin{array}{c}.43^{* *} \\
{[.43, .43]}\end{array}$ & $\begin{array}{c}.56^{* *} \\
{[.56, .56]}\end{array}$ & $\begin{array}{c}.49 * * \\
{[.49, .49]}\end{array}$ & $\begin{array}{l}.67 * * \\
{[.67, .68]}\end{array}$ & $\begin{array}{l}.78^{* *} \\
{[.78, .79]}\end{array}$ & $\begin{array}{l}.78 * * \\
{[.78, .79]}\end{array}$ & & & & & \\
\hline Training & 3.46 & 1.13 & $\begin{array}{c}.38 * * \\
{[.38, .38]}\end{array}$ & $\begin{array}{l}.41 * * \\
{[.40, .41]}\end{array}$ & $\begin{array}{l}.56^{* *} \\
{[.56, .56]}\end{array}$ & $\begin{array}{l}.46^{* *} \\
{[.45, .46]}\end{array}$ & $\begin{array}{l}.56 * * \\
{[.56, .57]}\end{array}$ & $\begin{array}{l}.54 * * \\
{[.53, .54]}\end{array}$ & $\begin{array}{l}.59 * * \\
{[.59, .59]}\end{array}$ & $\begin{array}{c}.58 * * \\
{[.58, .58]}\end{array}$ & & & & \\
\hline Workload & 3.36 & 1.18 & $\begin{array}{c}.30 * * \\
{[.30, .30]}\end{array}$ & $\begin{array}{c}.26^{* *} \\
{[.26, .26]}\end{array}$ & $\begin{array}{l}.42 * * \\
{[.42, .43]}\end{array}$ & $\begin{array}{c}.35^{* *} \\
{[.34, .35]}\end{array}$ & $\begin{array}{c}.39 * * \\
{[.38, .39]}\end{array}$ & $\begin{array}{l}.43^{* *} \\
{[.42, .43]}\end{array}$ & $\begin{array}{l}.44 * * \\
{[.44, .44]}\end{array}$ & $\begin{array}{l}.44 * * \\
{[.44, .44]}\end{array}$ & $\begin{array}{l}.39 * * \\
{[.39, .39]}\end{array}$ & & & \\
\hline Woman & 0.44 & 0.50 & $\begin{array}{c}-.04 * * \\
{[-.05,-.04]}\end{array}$ & $\begin{array}{c}-.05 * * \\
{[-.05,-.04]}\end{array}$ & $\begin{array}{c}-.03 * * \\
{[-.03,-.03]}\end{array}$ & $\begin{array}{c}-.01 * * \\
{[-.01,-.01]}\end{array}$ & $\begin{array}{c}-.02 * * \\
{[-.02,-.02]}\end{array}$ & $\begin{array}{c}-.02 * * \\
{[-.02,-.01]}\end{array}$ & $\begin{array}{c}-.01 * * \\
{[-.02,-.01]}\end{array}$ & $\begin{array}{l}-.00 \\
{[-.00, .00]}\end{array}$ & $\begin{array}{c}-.02 * * \\
{[-.02,-.01]}\end{array}$ & $\begin{array}{c}-.04 * * \\
{[-.04,-.03]}\end{array}$ & & \\
\hline Supervisor & 0.19 & 0.39 & $\begin{array}{l}.07 * * \\
{[.07, .07]}\end{array}$ & $\begin{array}{c}.09 * * \\
{[.09, .09]}\end{array}$ & $\begin{array}{l}.07 * * \\
{[.07, .07]}\end{array}$ & $\begin{array}{l}.05 * * \\
{[.05, .06]}\end{array}$ & $\begin{array}{l}.11 * * \\
{[.11, .11]}\end{array}$ & $\begin{array}{l}.08 * * \\
{[.08, .09]}\end{array}$ & $\begin{array}{l}.08 * * \\
{[.08, .08]}\end{array}$ & $\begin{array}{l}.07 * * \\
{[.07, .08]}\end{array}$ & $\begin{array}{l}.09 * * \\
{[.09, .09]}\end{array}$ & $\begin{array}{c}-.06 * * \\
{[-.06,-.06]}\end{array}$ & $\begin{array}{c}-.10 * * \\
{[-.10,-.09]}\end{array}$ & \\
\hline Education & 2.08 & 0.80 & $\begin{array}{c}.09 * * \\
{[.09, .09]}\end{array}$ & $\begin{array}{l}.09 * * \\
{[.08, .09]}\end{array}$ & $\begin{array}{c}.03^{* * *} \\
{[.03, .04]}\end{array}$ & $\begin{array}{c}.05^{* *} \\
{[.05, .05]}\end{array}$ & $\begin{array}{l}.03 * * \\
{[.03, .04]}\end{array}$ & $\begin{array}{l}.04 * * \\
{[.04, .05]}\end{array}$ & $\begin{array}{l}.01 * * \\
{[.01, .01]}\end{array}$ & $\begin{array}{l}.04 * * \\
{[.03, .04]}\end{array}$ & $\begin{array}{l}.05^{* *} \\
{[.04, .05]}\end{array}$ & $\begin{array}{l}-.01 * * \\
{[-.02,-.01]}\end{array}$ & $\begin{array}{l}-.02 * * \\
{[-.03,-.02]}\end{array}$ & $\begin{array}{l}.10^{* * *} \\
{[.09, .10]}\end{array}$ \\
\hline
\end{tabular}

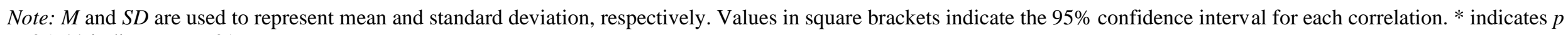
$<.05$. ** indicates $p<.01$. 